\title{
Laser Improves Biogas Production by Anaerobic Digestion of Cow Dung
}

\author{
Munaf S. Majeed ${ }^{{ }^{*}}$
}

Rabea Q. Nafil ${ }^{2}$

R. k. Fakher Alfahed ${ }^{1}$

Received 2/5/2018, Accepted 2/9/2018, Published 13/9/2018

This work is licensed under a Creative Commons Attribution 4.0 International License.

\begin{abstract}
:
This study investigates the digestion of cow dung (CD) for biogas production at laboratory scales. The study was carried out through anaerobic fermentation using cow dung as substrate. The digester was operated at ambient temperatures of $39.5{ }^{\circ} \mathrm{C}$ for a period of 10 days. The effect of iron powder in controlling the production of hydrogen sulfide $\left(\mathrm{H}_{2} \mathrm{~S}\right)$ has been tested. The optimum concentration of iron powder was $4 \mathrm{~g} / \mathrm{L}$ with the highest biogas production. A Q - swatch Nd:YAG laser has been used to mix and homogenize the components of one of the six digesters and accelerate digestion. At the end of digestion, all digestions effluent was subjected to 5 laser pulses with $250 \mathrm{~mJ} /$ pules to dispose waste biomass.
\end{abstract}

Keywords: Anaerobic digestion, Biogas production, Cow dung, Laser enhances digestion.

\section{Introduction:}

Organic waste, especially animal waste, is a major threat to the environment and human health as it causes unpleasant odors, harmful gases such as hydrogen sulfide $\left(\mathrm{H}_{2} \mathrm{~S}\right)$, a fertile environment for bacterial colonies, and a host of pathogenic viruses (1). So it is necessary to get rid of them in a convenient and inexpensive way. The researchers' attempt, is to turn it into another form that can be used to generate energy and produce biogas

Animal waste is burned to be disposed of, that causes environment pollution risk. An alternative technique is anaerobic digestion. If digestion is carried out in isolation from the air, a group of gases and organic acids of low atomic weights are produced, which can then be used for industry and energy generation (2). The overall result is methane, carbon dioxide, hydrogen sulfide, ammonia and new bacterial biomass $(3,4)$. Methane gas $\left(\mathrm{CH}_{4}\right)$ is the simplest of the alkanes and forms a $90 \%$ of the marsh gas where it is produced from the decomposition of organic matters, found in coal gas from coal-fired distillation, and it is one of the main components of natural gas rising from oil wells (5, $6)$. It is also prepared in laboratory from the addition of hydrochloric acid to water and aluminum carbide. In addition to being $80 \%$ of the natural gas used as fuel, methane gas is used in the preparation of many organic compounds such as chloroform, which is used as an anesthetic and

${ }^{1}$ Biomass Department, Nano renewable Energy Research Center, Al Nahrian University, Iraq

${ }^{2}$ Applied Physics Branch, Applied Sciences Department, University of Technology, Iraq

* Corresponding author: munafsm76@gmail.com carbon tetrachloride used in firefighting. It is also used in many industries such as plastics, nylon, alcohol and others.

The production of biogas by anaerobic digestion of livestock waste has gained its importance in that it contributes to the disposal of organic waste in a clean and safe manner on the one hand and works to restore energy from waste on the other hand (5). This method has been tested on many types of organic waste such as food waste $(7)$, poultry $(8,9)$, and livestock waste (10). The common objective of all studies is to produce biogas at the lowest cost and market quantities. Current research uses the cow dung as a raw material for the production of methane used in natural gas in an easy, inexpensive and effective manner in the treatment of animal waste. Laser and iron powder have been employed to enhance methane production and control production of hydrogen sulfide.

\section{Materials and Methods: \\ Collection of Waste and Iron Scrap}

Feedstock for this work was cow dung (CD) which was collected from slaughter house and animal, farm of the college of Agriculture, Baghdad University, Baghdad, Iraq.

Computerized Numerically Controlled (CNC) machine works on cutting iron template according to the desired design. Remaining from the template outside the design will be re-melt and recycled, while iron filings are discarded as waste. In the current research, the machine was used to grind the iron residue and form a powder which is later used to feed anaerobic digestion process. 


\section{Sample Preparation}

The wastes were sorted to separate domestic and plant materials were subsequently characterized. The cow dung was mixed with water outside the digester at the ratio 1:1. Six samples of this mixture were prepared. The first sample $\left(S_{0}\right)$ is free of iron filings and has not been treated with laser. In samples; $S_{1}, S_{2}, S_{3}$, and $S_{4}$, iron powders were added to the mixture at concentrations; $(1,2,3,4)$ $\mathrm{g} / \mathrm{L}$ respectively. Based on the best results obtained from the previous five samples, the sixth sample $\left(\mathrm{S}_{5}\right)$ was prepared, also mixed with $4 \mathrm{~g} / \mathrm{L}$ iron powder but was processed with laser. Anaerobic digestion consists of a series of microbial processes that convert waste organic matter to biogas. It is a relatively slow process, therefore; an Nd:YAG laser with few millijoule pulsed energy has been used to ignite decomposition in $\mathrm{S}_{5}$. Also, this sample has been mixed well and homogenized by 3-4 laser pulses before feeding to the digester.

\section{Experimental Procedures}

All the samples were fed to the digesters and allowed to ferment anaerobically for 10 days. The experiments were carried out in lab-reactors of $1 \mathrm{~L}$ colonial effective volume flask. This study was carried out anaerobically at mesophilic condition $\left(39.5^{\circ} \mathrm{C}\right)$. The sample $\mathrm{S}_{\mathrm{o}}$ was used as a reference while the samples $S_{1}-S_{4}$ were used for investigating the reduction of hydrogen sulfide by iron powder. The role of laser in accelerating anaerobic digestion was tested depending on results obtained from sample $\mathrm{S}_{5}$.

The biogas was collected in 2-L containers with gas production monitored using a gas flow meter. The gas composition was analyzed using a gas chromatograph. Methane production was monitored on a daily basis and observations were made.

After the end of incubation period, the waste resulting from the anaerobic digestion was placed in an exposed container for three days and then bombarded with a number of laser pulses. This step is necessary for the disposal of the bacterial colonies produced during the fermentation and anaerobic digestion period, thus producing biogas in an environmentally friendly way.

\section{Results and Discussion:}

The performance of anaerobic digestion of cow dung was studied based on the results obtained from the monitoring of the amount of methane produced and the change of the concentration of $\mathrm{H}_{2} \mathrm{~S}$. The effect of laser was also investigated in accelerating digestion as well as eliminating the remaining bacterial colonies in the residues after the end of anaerobic digestion. The results were as follows:

\section{Methane Production}

Figure 1 shows methane production during the study period. It is noted from the figure that the production of $\mathrm{CH}_{4}$ was slow in sample $\mathrm{S}_{0}$ as it began from the fourth day and can be explained by the fact that the first three days were the growth period of methanogenic bacteria.

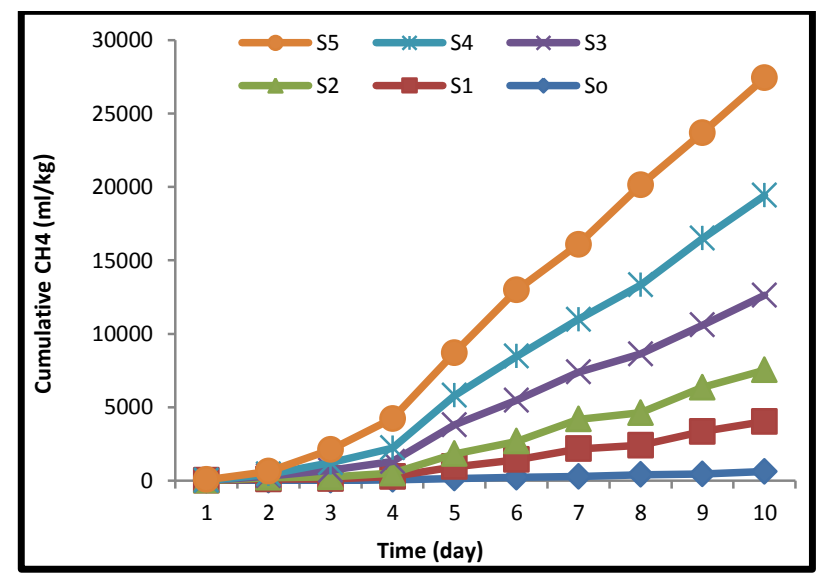

Figure 1. Cumulative biogas production.

The same Fig. shows that $\mathrm{CH}_{4}$ production in the samples $\mathrm{S}_{1}-\mathrm{S}_{4}$ began from the second day (i.e. before the growth of microbial), this was due to the interaction of the iron powder with the water to produce the hydrogen, which in turn combined with the carbon dioxide to form methane (11), according to the following equations:

$$
\begin{aligned}
& \mathrm{Fe}+2 \mathrm{H}_{2} \mathrm{O} \rightarrow \mathrm{FeO}_{2}+2 \mathrm{H}_{2} \\
& 4 \mathrm{H}_{2}+2 \mathrm{CO}_{2} \rightarrow \mathrm{CH}_{4}+2 \mathrm{H}_{2} \mathrm{O}
\end{aligned}
$$

After the contribution of methanogen in the third day, the amount of methane produced in samples $S_{1}$ $-S_{4}$ increased as compared to the reference sample $\mathrm{S}_{\mathrm{o}}$. In sample $\mathrm{S}_{5}$, laser pulses provided enough energy to break up water molecules and oxidize iron powder and thus produced larger quantities of $\mathrm{H}_{2}$ to produce methane on the first day. This reaction is similar to that of samples $S_{1}-S_{4}$. Laser pulses also worked on decomposing the organic matter, which facilitated the task of bacteria in digesting cow dung and also formed a suitable incubation environment for the growth of methanoginc colonies. This explains the rapid production of methane in sample $\mathrm{S}_{5}$ and in larger quantities compared with the rest of the samples.

\section{Hydrogen Sulfide $\left(\mathrm{H}_{2} \mathrm{~S}\right)$ Reduction}

Hydrogen sulfide was generated in all digesters during incubation period as shown in Fig.2. It is obvious that the reference digester generated higher $\mathrm{H}_{2} \mathrm{~S}$ than those with $\mathrm{Fe}$ powder. 


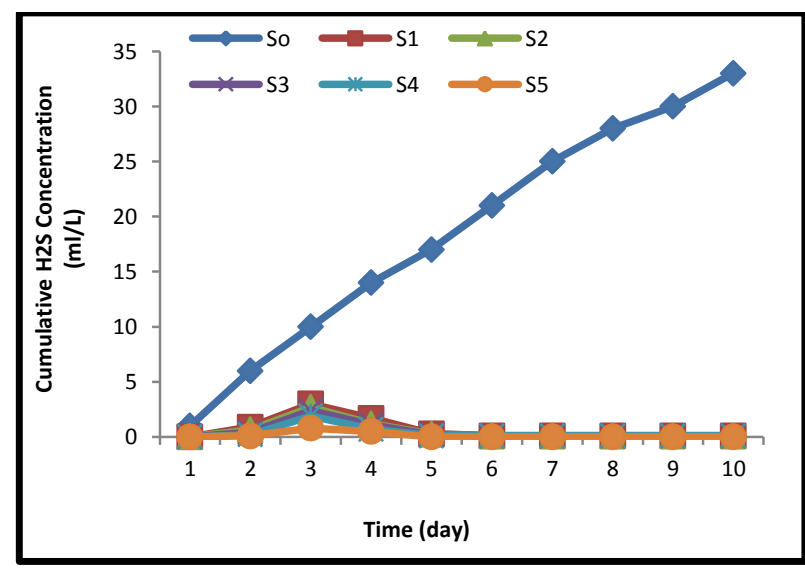

Figure 2. Cumulative Hydrogen sulfide

In digesters $S_{1}-S_{5}$, the substrate blackens increased with increasing iron powder concentration. This gives an observable indication that ferrous sulfide precipitate was produced. Thus the reduction of $\mathrm{H}_{2} \mathrm{~S}$ was assumed to be due to the formation of $\mathrm{FeS}$ (11), according to the relation:

$\mathrm{Fe}+\mathrm{H}_{2} \mathrm{~S} \rightarrow \mathrm{FeS}+\mathrm{H}_{2}$

The laser-treated digester showed the lowest concentration of hydrogen sulfide. This can be attributed to the role of the laser in accelerating iron corrosion and thus facilitate the interaction mentioned in equation 3 .

\section{Disposals Waste Biomass by Laser}

Wet biomass effluent absorbed more thermal energy than it can supply; therefore waste biomass must be dried to burn. In this work, 15 laser pulses have been used to perform drying and burning task. Each pulse has $250 \mathrm{~mJ}$. This high energy helped to evaporate liquids in biomass wastes and accelerate drying, and hence burning them in a clean and environmentally friendly manner.

\section{Conclusions:}

Based on the aforementioned results, cow dung affects the total biogas yield. This may be because the cow dung has high carbohydrate and fat content which shows that it contains high energy yielding nutrients. This research has shown that flammable biogas can be produced from this waste through anaerobic digestion. The (CD) waste is always available in our environment and can be used as a source of fuel if managed properly.

Also in this study, it has been found that iron powder has the ability to eliminate hydrogen sulfide, which is responsible for damaging the digester and raising the cost of production
The laser has an effective role in mixing and homogenizing the components of the digester and accelerating the anaerobic digestion. It also contributes to the releasing of larger quantities of hydrogen, which leads to increasing the amount of methane produced. It can also be considered as an environmentally friendly way of disposing biomass waste

\section{Conflicts of Interest: None.}

\section{References:}

1. Ibn Abubakar B, Ismail N. Anaerobic Digestion of Cow Dung for Biogas Production; ARPN JEAS. 2012 February;7(2): 169-172.

2. Aremu M, Agarry S. Comparison of Biogas production from Cow Dung and Pig dung under Mesophilic condition. IRJES. 2011 December;1(4): 16-21.

3. Adiotomre K, Ukrakpor E. Production of Biogas from Kitchen Waste and Cow Dung. IJISETR. 2015April; 3(2):52-64.

4. Stephen C, Ukpabi C, Esihe T. Anaerobic Digester Considerations of Animal Waste. SAPAJB. 2013;3(4): 93- 96.

5. Okonkwo U. Onokpite E. Onokwai A. Comparative study of the optimal ratio of biogas production from various organic wastes and weeds for digester/restarted digester. JKSUES. 2016;2:36391018.

6. Lawrie J. Chemicals from Methane. Nature. 1947 May;159:24.

7. Mydin M. Abllah N. Sani N, Ghazali N. Zahari N. Generating Renewable Electricity from Food Waste; E3S Web of Conferences 3. 01012 (201). 2014; Available at http://www.e3s-conferences.org.

8. Farrow C. Anaerobic Digestion of Poultry Manure: Implementation of Ammonia Control to Optimize Biogas Yield: Poultry Manure Digestion; PhD dissertation. Guelph Canada: University of Guelph; 2016.

9. Ahamed J. Raiyan M. Hossain M. Rahman M. Salam B. Production of biogas from anaerobic digestion of poultry droppings and domestic waste using catalytic effect of silica gel. IJAME. 2016 September. 13(2): $3503 \quad-\quad 3517$.Available at https://doi.org/10.15282/ijame.13.2.2016;17.0289.

10. Angelidaki I. Ahring B. Thermophilic anaerobic digestion of livestock waste: the effect of ammonia. AMB 1993;38:560-564.

11. Agani I, Suanon F, Dimon B, Ifon E, YovoF, Wotto $\mathrm{V}$, et al. Enhancement of Fecal Sludge Conversion Into Biogas Using Iron Powder During Anaerobic Digestion Process. AJEP.2016;5(6):179-186. 


\section{الليزر يحسن إنتاج الغاز الحيوي من الهضم اللاهوائي لروث البقر}

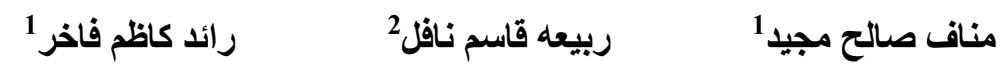

1 قسم الكتله الحيويه، مركز بحوث النهرين للطاقه المتجدده النانويه، جامعة النهرين، العر اق. 2 فرع الفيزياء التطبيقيه، قسم العلوم التطبيقيه، الجامعه التكنولوجيه لأنيه، العر اق.

تبحث هذه الدراسة في هضم روث البقر (CD) لإنتاج الغاز الحيوي في المقاييس المختبرية. وقد أجريت الدراسة من خلال التخمير

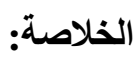

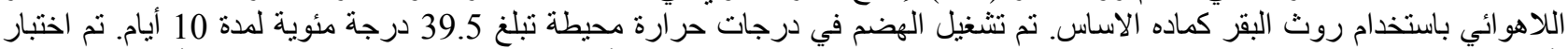

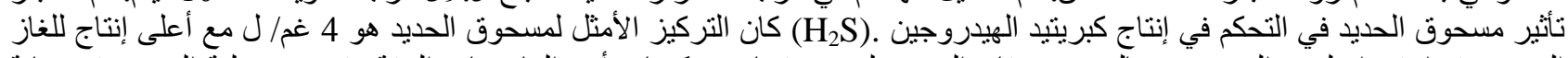

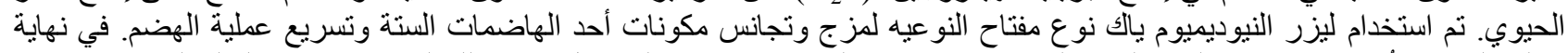

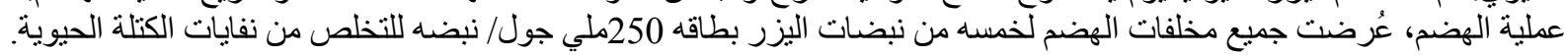

الكلمات المفتاحية: الهضم الاهوائي، انتاج الغاز الحيوي، روث الابقار، اليزر يحسن الهضم. 